\title{
GROW-OUT OF NORTHERN PIKE (ESOX LUCIUS L.) LARVAE UNDER UNCONTROLLED CONDITIONS
}

\author{
Bogusława WOLSKA-NEJA1 , Zbigniew NEJA2* \\ ${ }^{1}$ Division of Hydrobiology, ${ }^{2}$ Division of Biological Marine Resources; Agricultural University of Szczecin, Poland
}
Wolska-Neja B., Neja Z. 2006. Grow-out of northern pike (Esox lucius L.) larvae under uncontrolled con- ditions. Acta Ichthyol. Piscat. 36 (2): 105-112.

\begin{abstract}
Background. This study aimed to determine survival rate, extent of cannibalism, and growth rate of northern pike (Esox lucius L.) larvae fed live zooplankton during a grow-out period, i.e., the time prior to when fish become valuable as stocking material. An attempt was also made to assess the food conversion ratio (FCR) with respect to the natural food applied. Materials and Methods. Grow-out operations began with 1-day-old pike larvae and involved experimental in-ground tanks with no artificial aeration, forced water flow, artificial circadian lighting, or temperature control. Differently structured habitats (black polyethylene foil, vascular plants, or plastic netting) were placed in all the tanks to separate larvae and provide cover. Feeding live zooplankton to the larvae began on day 3 and food was administered such that larvae were always surrounded by a zooplankton "cloud."

Results. The survival rate during the first- (days 1-7) and second (days 8-27) stage of culture was $92.3 \%$ and $95.7 \%$, respectively. Highest survival rates were associated with tanks with polyethylene foil habitats, while lowest survival rates were associated with tanks containing plastic netting. No cannibalism was observed in any tank. During the growout period, the total length of larvae increased by an average of $20.88 \mathrm{~mm}$. Although the length increase observed in the three experimental treatments was similar; the significantly highest $(P<0.01)$ mean length $(32.66 \mathrm{~mm})$ was associated with larvae raised in tanks containing polyethylene foil. Until day 13, the mean weight of the larvae did not differ between the three treatments $(P=0.21)$. At and beyond day 20 , fish kept in tanks equipped with polyethylene foil exhibited higher weight increments and on termination of the experiment the mean individual weight of larvae was significantly higher $(P<0.05)$ than those of larvae in tanks with vascular plants and plastic netting. The food conversion ratio, calculated for the entire culture period was 4.9 .

Conclusion. High survival rate of the cultured pike larvae demonstrated the success of pike larvae grow-out under uncontrolled conditions.
\end{abstract}

Keywords: fish, pike, Esox lucius, larvae, larval grow-out, crustacean diet

\section{INTRODUCTION}

Because of the decreasing abundance of northern pike (Esox lucius L.) in Polish waters (Szczerbowski 1993), cultured pike fry are particularly valuable for stock enhancement (Johnson et al. 1992). Studies investigating methods of pike grow-out reveal a trend of culture operations being strictly controlled and larvae being fed artificial food (Wolnicki and Górny 1995, 1997, Wolnicki and Kamiński 1998). One reason for not feeding pike larvae live food probably stems from the difficulty of providing an adequate amount of such food during the culture period (Adamek 1986, Poczyczyński 1996), as an inadequate food supply is one of the major causes of cannibalism in pike larvae (Załachowski 1970, Skov et al. 2003). However, not feeding zooplankton to pike larvae during the first period of exogenous feeding also has other adverse consequences. For example, Łuczyński (1992) demonstrated that pike larvae, fed live zooplankters, exhibited better condition and were more resistant to pathogens when compared to larvae fed artificial feeds. One reason for such results stems from the fact that the activity of digestive enzymes in fish larvae is lower than that in conspecific adults (Łuczyński 1992). Thus, the deficiency of proteolytic enzymes in larvae is partly compensated for by enzymes contained in the zooplankton digested (Poczyczyński 1996). In an effort to contribute to our understanding of the husbandry of pike larvae, the purpose of this study was to determine survival, cannibalism, and growth rates of pike larvae reared on live feed under uncontrolled conditions. 


\section{MATERIALS AND METHODS}

Pike grow-out operations began on 3 May 1997, with 1-day-old larvae obtained from the Division of Fish Anatomy and Embryology, Agricultural University of Szczecin. Larvae were transferred from a Weiss apparatus to six outdoor, 13-L, plastic containers embedded $15 \mathrm{~cm}$ in the ground and filled with tap (chlorinated) water. Water temperature in the tanks fluctuated in synchrony with air temperature variations, the changes being particularly extensive during sunny days (up to $9^{\circ} \mathrm{C}$ ). Because water condition in the study tanks was not controlled (e.g., cf. with conditions detailed in Górny 1992, Wang and Eckmann 1992, Górny and Wolnicki 1993, Gres et al. 1996), nor did they mimic natural conditions (e.g., cf. with conditions detailed in Mejza et al. 1996, Desvilettes et al. 1997, Morrow et al. 1997), we considered our grow-out operation to represent uncontrolled field conditions.

Each grow-out tank contained one of three types of habitat that provided shelter and separated pike larvae from each other, thus preventing cannibalism. The three types of habitats used were:

- black-colored, heavy-duty polyethylene gardening foil strengthened with copper wire; tanks F1 and F2;

- vascular plants (Ceratophyllum demersum, Elodea canadensis); tanks R1 and R2;

- plastic netting (2.83 $\mathrm{mm}$ mesh diameter) strengthened with copper wire; tanks S1 and S2; tanks were covered with a protective netting to prevent contamination and to ward predators.

Each tank was stocked with 100 larvae 8.74 to 9.94 $\mathrm{mm}$ long (total length, measured to $0.02 \mathrm{~mm}$ ); average larva length was $9.32 \mathrm{~mm}$. On day 7, the stocking density was reduced, by randomly removing larvae, to achieve a density of 50 larvae per tank ( 3.8 individuals per $\mathrm{L}$ ). The feeding of larvae began when they were 3 days old, initially by offering small planktonic crustaceans, mainly Cyclops strenuus (various developmental stages, with stage-V copepodids predominant) harvested from a natural water body and juvenile Daphnia magna. The cladocerans were cultured as described by Wolska-Neja (2002). As of day 7, pike were exclusively fed Daphnia magna of various size. Pike in all tanks were fed at identical frequen- cies and identical amounts per day. Throughout the 26-day experiment, larvae were surrounded by a zooplankton "cloud."

To determine growth in length and weight, 1-, 7-, 13-, 20-, and 27-day-old larvae were sampled. At each sampling, 10 larvae were harvested per tank, fixed in 5\% formaldehyde, measured with calipers (total length) to 0.01 $\mathrm{mm}$, and weighed (10 larvae together) to $0.0001 \mathrm{~g}$. Gut contents of all fed and measured larvae $(n=240)$ were examined to look for evidence of cannibalism. The food conversion ratio was estimated by dividing the mean amount of food (zooplankton wet weight) applied to a tank up to the sampling time to single larvae by the mean larval weight increment during the same time period. Zooplankton wet weight was calculated as described by Wolska-Neja (2002). Significance of differences in survival rates and mean larval lengths and weights among culture treatments were each tested using a one-way ANOVA and Student's t-test for small samples $(n<30)$.

\section{RESULTS}

Larval survival rate during the first stage of the experiment (days 1-7) averaged $92.3 \%$ and ranged from $72.0 \%$ to $99.0 \%$, regarding all treatment tanks (Table 1). Although this stage involved larval acclimatization to culture tank conditions and switching to exogenous feeding, pronounced losses $(28 \%)$ were recorded in only a single tank (tank S1 with netting barriers). The mean survival rate during the second experimental stage (days 8-27) was higher and averaged $95.7 \%$. Higher survival rates (100.0\% and $96.7 \%$ ) during this period were associated with the polyethylene foil-containing tanks, while only slightly lower rates $(100.0 \%$ and $93.3 \%)$ were associated with tanks containing plants (Table 1$)$. The significantly $(P<$ $0.05)$ lowest survival $(83.3 \%)$ during the second experimental stage was observed in the tanks equipped with netting barriers. Overall, evidence of cannibalism was not observed in any tank throughout the study or via the examination of gut contents of sampled larvae. During the 26 days of the experiment, the total length of the larvae increased by an average of $20.88 \mathrm{~mm}$. The longest mean length at the end of the experiment $(32.66 \mathrm{~mm})$ was cal-

\section{Table 1}

Survival rate [\%] of pike larvae reared under uncontrolled conditions; tanks F1 and F2 with black garden polyethylene foil; tanks R1 and R2 with vascular plants; tanks $\mathrm{S} 1$ and S2 with plastic netting

\begin{tabular}{cccccccc}
\hline \multirow{2}{*}{ Culture stage } & \multicolumn{8}{c}{ Tank } \\
\cline { 2 - 8 } & F1 & F2 & R1 & R2 & S1 & S2 & Mean \\
\hline $\begin{array}{c}\text { First } \\
\text { (1-7 days post hatching) }\end{array}$ & 95 & 99 & 99 & 91 & 72 & 98 & 92.3 \\
$\begin{array}{c}\text { Second } \\
(8-27 \text { days post hatching) }\end{array}$ & 100 & 96.7 & 93.3 & 100 & 83.3 & 83.3 & 95.7 \\
\hline
\end{tabular}




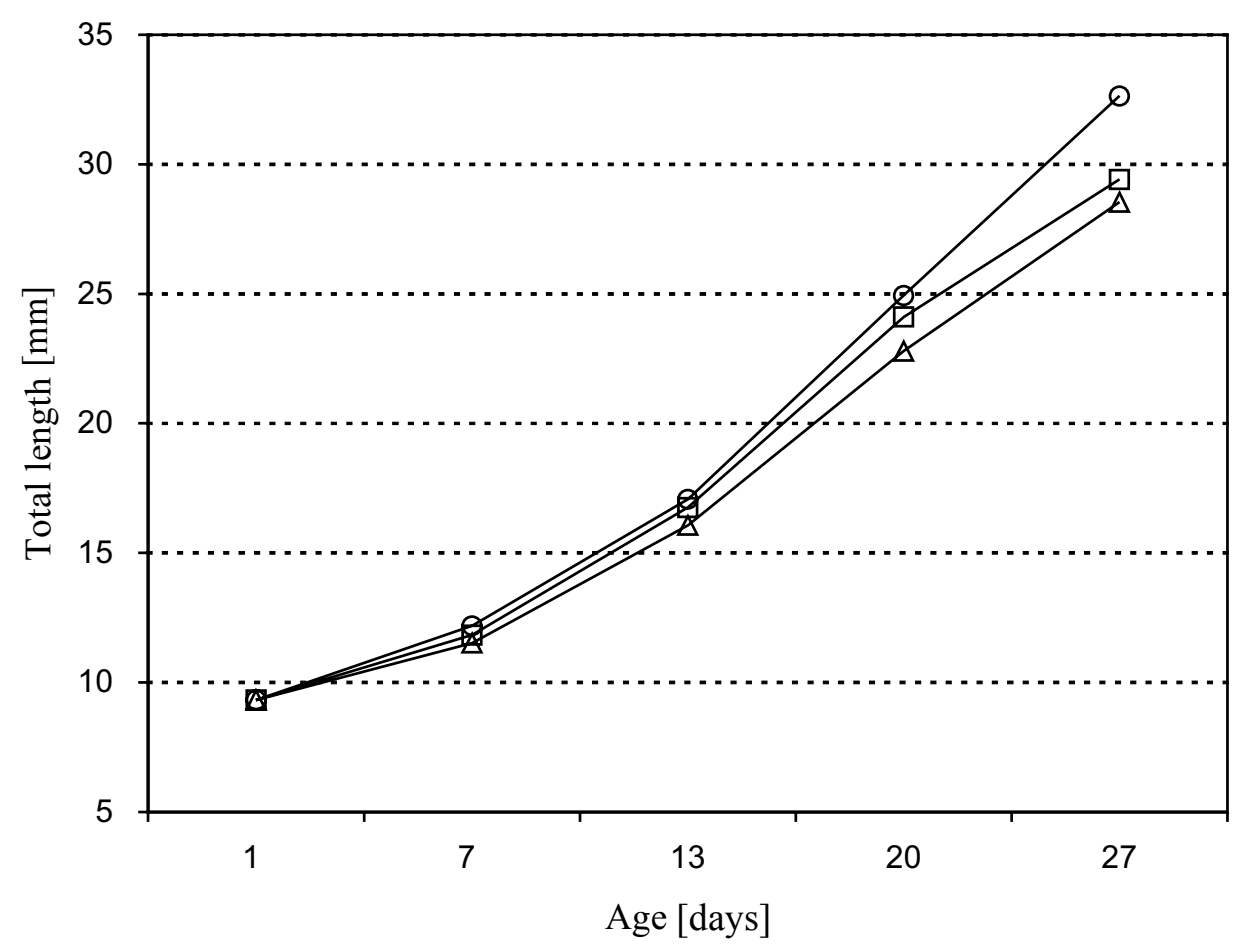

Fig. 1. Mean length [mm] of pike larvae during the growing-out operation in tanks with different habitats; tanks with black garden polyethylene foil (F) denoted with $\bigcirc$; tanks with vascular plants (R) denoted with $\square$; tanks with plastic netting (S) denoted with $\triangle$

culated for larvae reared in tanks containing black polyethylene foil (Fig. 1) and was significantly higher $(P<0.01)$ than mean lengths recorded for larvae reared in the netting- and plant-equipped tanks, the latter two treatments were not significantly different $(P=0.08)$.
The changes in growth (length) rate were similar in all the treatments until day 20 of larval life (Fig. 2). A slight acceleration of the larval growth was observed between day 13 and 20 only in F1. Past day 20 of culture, the mean growth rate was observed to decrease in all the treatments

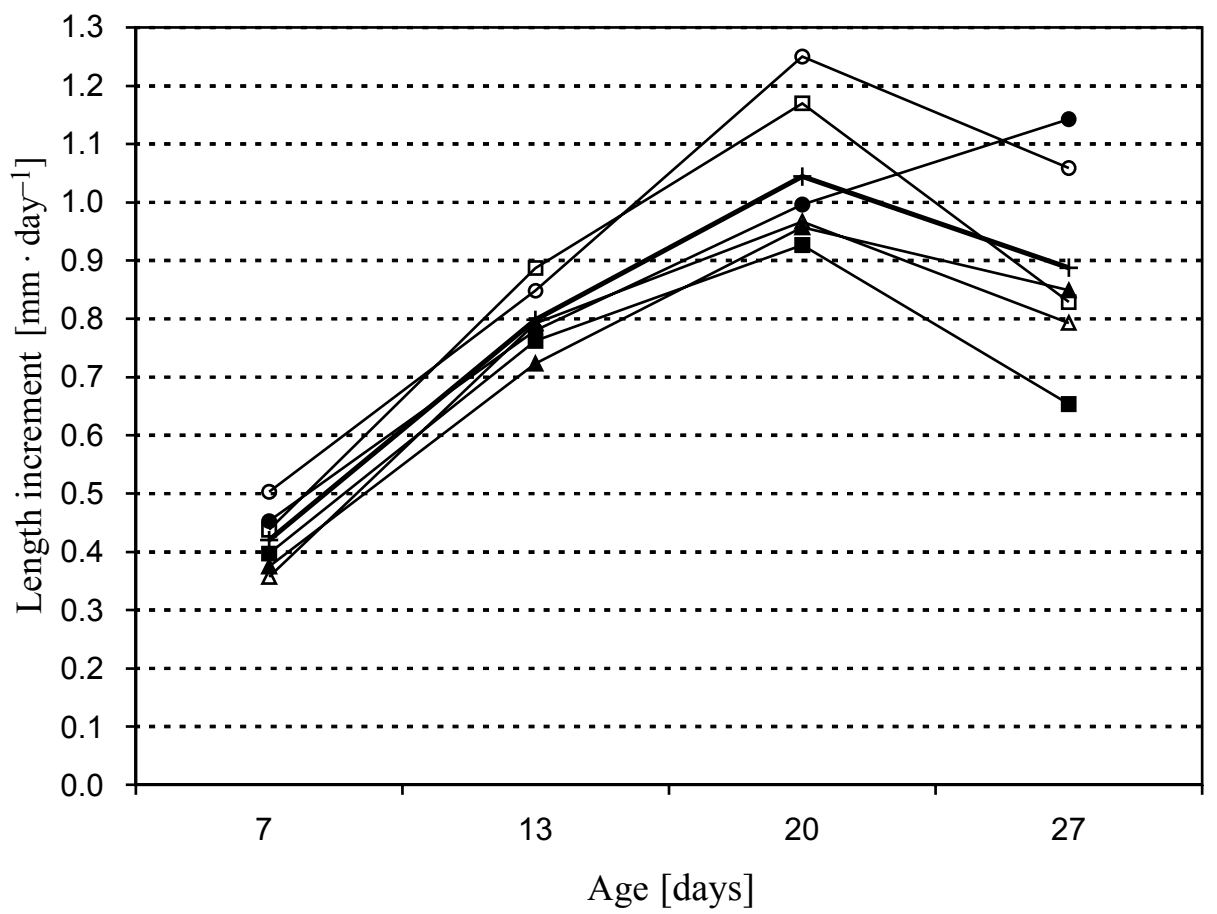

Fig. 2. Growth rate of pike larvae during growing-out operation in tanks with different habitats; tanks with black garden polyethylene foil (F1, F2) denoted with $\bigcirc$ and $\boldsymbol{\bullet}$; tanks with vascular plants (R1, R2) denoted with $\square$ and $\mathbf{\square}$; tanks with plastic netting (S1, S2) denoted with $\triangle$ and $\mathbf{\Delta} ; 1,2$, replicates; arithmetic mean denoted with + 
except for F2. The decrease coincided with a decrease in water temperature in the tanks (Table 2).

Individual growth (weight) increment over the 26 days of culture averaged $298.5 \mathrm{mg}$ (Table 3). Until day 13 of larval life, the mean individual weight did not differ significantly $(P=0.21)$ among the treatments (Fig. 3$)$. On day 20, the larvae in treatments $\mathrm{F}$ and $\mathrm{R}$ were heavier than those kept in tanks with netting, but differences in mean weights still were not significant $(P>0.05)$. As of day 20, $F$ treatment larvae showed decidedly higher weight increments and this trend continued until the experiment's termination (Fig. 3), when the larvae in F treatment exhibited a significantly higher $(P<0.05)$ mean individual weight than did larvae in treatments $\mathrm{R}$ and $\mathrm{S}$. The food conversion ratio, calculated for the entire length of the experiment, was 4.9 and varied during the study from 0.9 to 6.1 (Table 3 ). The best ratio (0.9) was observed during the first stage of the grow-out operation.

\section{DISCUSSION}

Survival rate is an important indicator of fish rearing success. The $92.3 \%$ survival rate observed in this study during stage one, a period of feeding transition for the larvae, as well as the survival rate of $95.7 \%$ recorded on termination of the 26-day-long rearing period confirmed that the grow-out operations under uncontrolled field conditions can be successful for pike. Controlled experiments using newly hatched pike larvae showed varying survival rates: 54\%-80\% (Górny 1992), 18\%-74\% (Luczyński 1992), and 25.8\%-88.0\% (Luczyńskiet et al. 1993). According to Górny (1992) and Łuczyński (1992), the survival rate decreases with increasing temperature of culture. In addition, Bry et al. (1992) observed a positive correlation between larval pike mortality and stocking density. In this experiment, water temperature was identical in all experimental tanks and fish density was identical at the beginning of the experiment. Thus, the observed differences in

Table 2

Mean growth (total length) [mm] of pike larvae reared under uncontrolled conditions; tanks F1 and F2 with black garden polyethylene foil; tanks R1 and R2 with vascular plants; tanks S1 and S2 with plastic netting; $s$, standard deviation; $\mathrm{CV}$, coefficient of variation

\begin{tabular}{|c|c|c|c|c|c|c|c|c|}
\hline $\begin{array}{l}\text { Age } \\
\text { [days] }\end{array}$ & $\begin{array}{c}\text { Mean } \\
\text { water } \\
\text { temperature } \\
{\left[{ }^{\circ} \mathrm{C}\right]}\end{array}$ & Tank & $\begin{array}{c}\text { Length range } \\
{[\mathrm{mm}]}\end{array}$ & $\begin{array}{l}\text { Mean } \\
\text { length } \\
{[\mathrm{mm}]}\end{array}$ & $n$ & $s$ & $\mathrm{CV}$ & $\begin{array}{c}\text { Mean growth } \\
{[\mathrm{mm}]}\end{array}$ \\
\hline 2 & & $\mathrm{~F}, \mathrm{R}, \mathrm{S}$ & $8.74-9.94$ & 9.32 & 10 & 0.423 & 4.534 & - \\
\hline \multirow[t]{6}{*}{7} & \multirow[t]{6}{*}{13.5} & F 1 & $11.70-12.84$ & 12.34 & 10 & 0.343 & 2.780 & 3.02 \\
\hline & & F 2 & $11.68-12.54$ & 12.04 & 10 & 0.320 & 2.654 & 2.72 \\
\hline & & R 1 & $11.50-12.60$ & 11.95 & 10 & 0.355 & 3.000 & 2.63 \\
\hline & & $\mathrm{R} 2$ & $10.80-12.20$ & 11.70 & 10 & 0.383 & 3.273 & 2.38 \\
\hline & & S 1 & $11.10-11.90$ & 11.46 & 10 & 0.243 & 2.123 & 2.14 \\
\hline & & S 2 & $11.14-11.88$ & 11.57 & 10 & 0.218 & 1.883 & 2.25 \\
\hline \multirow[t]{6}{*}{13} & \multirow[t]{6}{*}{17.5} & F 1 & $15.10-18.16$ & 17.43 & 10 & 0.903 & 5.182 & 5.09 \\
\hline & & F 2 & $15.88-17.38$ & 16.72 & 10 & 0.504 & 3.014 & 4.68 \\
\hline & & R 1 & $16.58-17.78$ & 17.27 & 10 & 0.425 & 2.464 & 5.32 \\
\hline & & R 2 & $15.08-17.10$ & 16.27 & 10 & 0.620 & 3.814 & 4.57 \\
\hline & & S 1 & $15.84-16.76$ & 16.21 & 10 & 0.341 & 2.101 & 4.75 \\
\hline & & S 2 & $14.26-17.00$ & 15.91 & 10 & 0.807 & 5.071 & 4.34 \\
\hline \multirow[t]{6}{*}{20} & \multirow[t]{6}{*}{18.5} & F 1 & $24.40-27.52$ & 26.18 & 10 & 1.242 & 4.744 & 8.75 \\
\hline & & F 2 & $22.70-25.10$ & 23.69 & 10 & 0.754 & 3.183 & 6.97 \\
\hline & & R 1 & $22.80-27.80$ & 25.46 & 10 & 1.563 & 6.139 & 9.19 \\
\hline & & R 2 & $20.48-24.90$ & 22.76 & 10 & 1.289 & 5.664 & 6.49 \\
\hline & & S 1 & $21.06-23.60$ & 22.98 & 10 & 0.795 & 3.460 & 6.77 \\
\hline & & S 2 & $21.48-23.50$ & 22.61 & 10 & 0.738 & 3.263 & 6.70 \\
\hline \multirow[t]{6}{*}{27} & \multirow[t]{6}{*}{16.6} & F 1 & $30.40-35.10$ & 33.59 & 10 & 1.685 & 5.017 & 7.41 \\
\hline & & F 2 & $28.96-34.82$ & 31.69 & 10 & 1.718 & 5.421 & 8.00 \\
\hline & & R 1 & $30.00-32.00$ & 31.26 & 10 & 1.140 & 3.646 & 5.80 \\
\hline & & R 2 & $24.58-29.60$ & 27.58 & 10 & 1.323 & 4.799 & 4.82 \\
\hline & & S 1 & $27.20-30.12$ & 28.53 & 10 & 1.238 & 4.340 & 5.55 \\
\hline & & $\mathrm{S} 2$ & $25.82-32.88$ & 28.55 & 10 & 1.864 & 6.529 & 5.94 \\
\hline
\end{tabular}


Table 3

Food ration (mg wet weight) and growth (weight) of pike larvae reared under uncontrolled conditions

\begin{tabular}{|c|c|c|c|c|c|c|c|}
\hline $\begin{array}{l}\text { Age } \\
\text { [days] }\end{array}$ & $\begin{array}{c}\text { Food ration } \\
{[\mathrm{mg}]}\end{array}$ & $\begin{array}{c}\text { No. of fish in } \\
\text { sample/stocking } \\
\text { density } \\
{\left[\text { inds. } \cdot \mathrm{L}^{-1}\right]}\end{array}$ & $\begin{array}{c}\text { Food ration } \\
\text { per fish } \\
{\left[\mathrm{mg} \cdot \text { ind }^{-1}\right]}\end{array}$ & $\begin{array}{c}\text { Mean } \\
\text { fish } \\
\text { weight } \\
\text { [mg] }\end{array}$ & $\begin{array}{l}\text { Growth } \\
\text { since } \\
\text { day } 1 \\
{[\mathrm{mg}]}\end{array}$ & $\begin{array}{l}\text { Growth } \\
\text { over } \\
\text { period } \\
{[\mathrm{mg}]}\end{array}$ & $\begin{array}{l}\text { Food } \\
\text { conversion } \\
\text { ratio }\end{array}$ \\
\hline 1 & - & $100 / 7.69$ & - & 8.90 & - & - & - \\
\hline 3 & 95.96 & $100 / 7.69$ & 0.96 & - & - & - & - \\
\hline 5 & 246.64 & $100 / 7.69$ & 2.47 & - & - & - & - \\
\hline 7 & 2346.43 & $50 / 3.85$ & 46.93 & 12.67 & 3.77 & 3.77 & 0.9 \\
\hline 8 & 2135.79 & $50 / 3.85$ & 42.72 & - & - & - & - \\
\hline 9 & 2407.26 & $50 / 3.85$ & 48.15 & - & - & - & - \\
\hline 10 & 626.60 & $50 / 3.85$ & 12.53 & - & - & - & - \\
\hline 13 & - & - & - & 37.34 & 28.44 & 24.67 & 6.1 \\
\hline 13 & 2792.72 & $40 / 3.08$ & 69.82 & - & - & - & - \\
\hline 15 & 4266.07 & $40 / 3.08$ & 106.65 & - & - & - & - \\
\hline 18 & 14521.88 & $40 / 3.08$ & 363.05 & - & - & - & - \\
\hline 20 & - & - & - & 152.21 & 143.31 & 114.87 & 4.7 \\
\hline 20 & 6395.69 & $30 / 2.31$ & 213.19 & - & - & - & - \\
\hline 22 & 11762.16 & $30 / 2.31$ & 392.07 & - & - & - & - \\
\hline 24 & 4674.87 & $30 / 2.31$ & 155.83 & - & - & - & - \\
\hline 27 & - & - & - & 307.38 & 298.48 & 155.17 & 4.9 \\
\hline
\end{tabular}

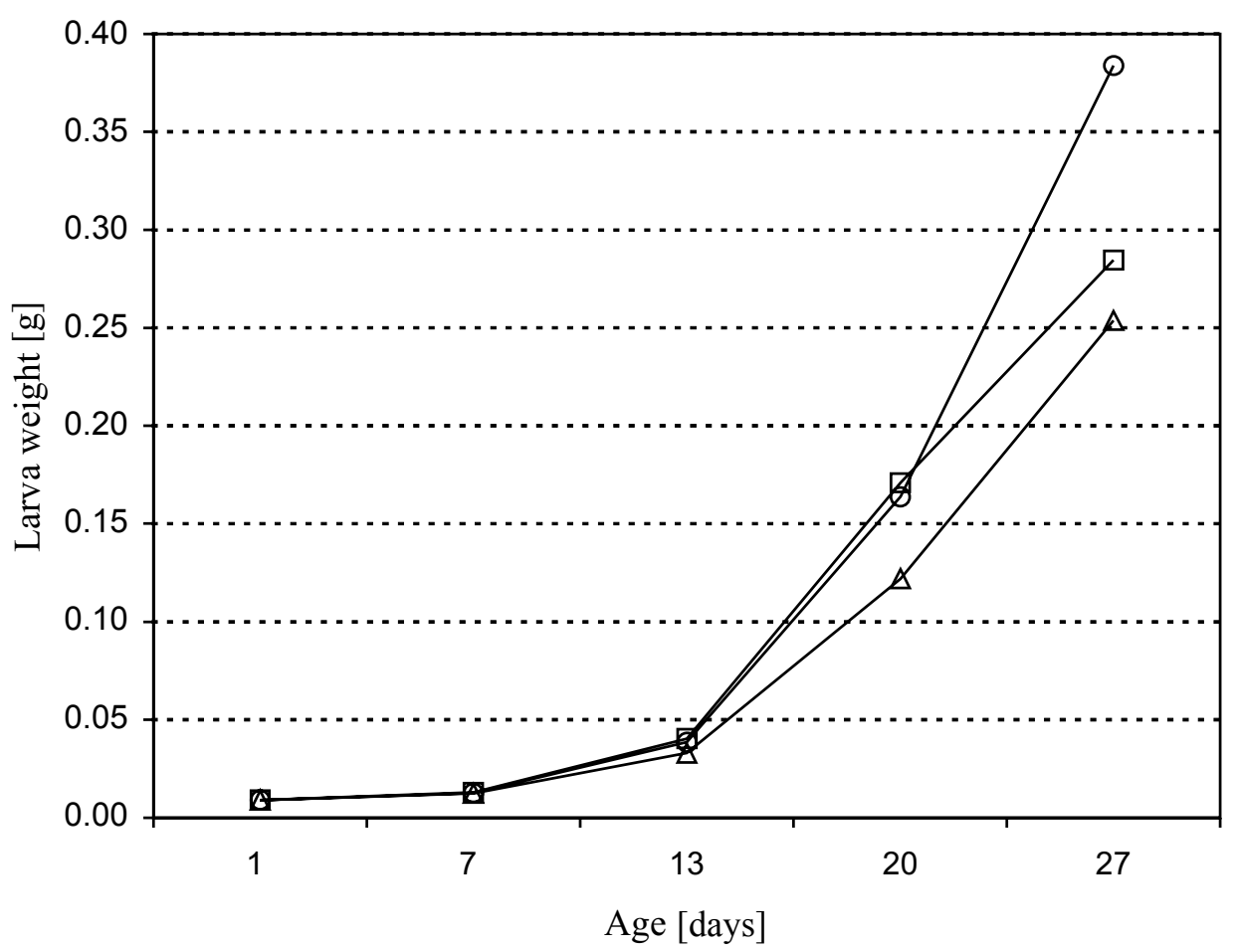

Fig. 3. Mean individual weight of pike larvae during growing-out operation in tanks with different habitats. Tanks with black garden polyethylene foil (F) denoted with $O$; tanks with vascular plants (R) denoted with $\square$; tanks with plastic netting (S) denoted with $\triangle$ 
survival rate were likely associated with differences in the type of structured habitat within the treatments. The highest survival, observed in tanks equipped with polyethylene foil barriers, could have been a result of the highest functionality of the barriers. Most probably, a beneficial effect of periphytic organisms that preferentially colonize polyethylene sheets submerged in water (Szlauer and SzlauerŁukaszewska 1994) played a role in that functionality. The periphyton, settled on an $0.42 \mathrm{~m}^{2}$ surface area in a relatively small volume of water (13 L), was likely important in reducing water contamination, and the effect of this probably intensified over time (Szlauer 1979, 1995, Szlauer and Świerczyńska 1988, Piesik et al. 1991). The highest losses of pike larvae occurred in tanks equipped with netting barriers, both during the first and second stage of the experiment. The use of plastic translucent netting may have resulted in some attack attempts, whereby larvae became physically damaged due to contact with the sharp and hard surface of the netting. Such damage probably caused mold to appear on the snouts of a few individuals, as observed at the end of the experiment. Said damage could also have been instrumental in increasing mortality rate among the larvae.

Since the beginning of exogenous feeding (day 8-10 of life), pike larvae were observed to hunt only moving objects (Załachowski 1973, Koch et al. 1982), including their conspecifics (Giles et al. 1986). Cannibalistic behavior occurs in very early larvae only when other food is not available (Załachowski 1970, Korwin-Kossakowski 1997). Cannibalism may also be provoked by size diversity among the fish (Giles et al. 1986, Desvilettes et al. 1997). Therefore, the absence of cannibalism in the pike larvae reared in this experiment probably resulted from three causes. Firstly, the larvae were always surrounded by an excess of food. Secondly, the larvae were very uniform in size on the onset: the largest differences within the newly hatched larvae was $0.8 \mathrm{~mm}$. Thirdly, the structured habitats efficiently prevented aggressive behavior. These conclusions are in agreement with Skov et al. (2003), who noted that highest survival in pike larvae was found among pike stocked in the "complex habitat."

Under natural conditions, pike larvae grow at an averaging rate of $0.5-0.7 \mathrm{~mm} \cdot$ day $^{-1}$ during the first 20 days of life (Franklin and Smith 1963). In an aquarium experiment, Ivanova and Svirskaâ (1995) determined larval growth rate as $0.12-0.80 \mathrm{~mm} \cdot$ day $^{-1}$. In a fully controlled rearing operation, when pike larvae were fed high-protein starter food, a growth rate of $1.8 \mathrm{~mm} \cdot$ day $^{-1}$ was observed (Wolnicki and Górny 1995). Thus, the larval growth rate of $0.75 \mathrm{~mm} \cdot \mathrm{day}^{-1}$ (average) reported here was close to that observed under natural conditions. Apart for temperature, the reduced growth rate of the larvae between the 20 and 27 day sampling periods may have been also caused by inappropriate food. Under natural conditions, pike larvae at that developmental stage (stage VIII of Załachowski 1970) show a sharp decline in the amount of zooplankton they ingest when they switch from feeding on crustaceans and insect larvae to consuming larvae of other fish. This dietary switch results in faster growth of juvenile pike (Załachowski 1970).

The nutritive value of live planktonic organisms as food is decidedly lower than that of concentrated feeds used in commercial rearing of fish larvae (Brett 1971, Marmulla and Rösch 1990). However, natural food has some advantages over commercial feed. Digestive enzyme activity is lower for fish larvae than that for conspecific adults, and the deficiency of proteolytic enzymes in larvae is partially compensated for by enzymes contained in the zooplankton they ingest (Poczyczyński 1996). Therefore, an energy-rich food is not always a better source of nutrition. The food conversion ratios obtained when feeding larvae natural vs. artificial foods are very different. Wolnicki and Górny (1995) reported an exceptionally favorable food conversion ratio when pike were fed high-protein starter (0.7); ratios of 1.3-1.7 were shown by other aquaculturists (Górny 1992, Szczepkowski et al. 1999). The cladoceran conversion ratio in juvenile pike is 11.5 (Karzinkin 1952), the copepod ratio being 17 (Scholz 1932). The conversion ratio of Daphnia magna and $C y$ clops sp. as food for the cultured pike larvae, calculated in this experiment as 4.9, can therefore be regarded as a good grow-out operation. It has to be added that food (plankton) losses due to natural mortality were not assessed. However, using results of Marmulla and Rösch (1990), who estimated such losses due to natural mortality at $18 \%-32 \%$, it may be assumed that the true food conversion ratio was lower and ranged from 4 to 3.3.

Sakowicz (1939) promoted stocking natural water bodies with fertilized or eyed eggs and newly hatched larvae as a way to increase the abundance of pike. However, better stocking effects are obtained by growing out the newly hatched larvae, even for a short time (Wolnicki and Górny 1993). It is thought that the length of $20-50 \mathrm{~mm}$, a length at which the larvae are efficient swimmers, is sufficient to qualify the larvae as quality stocking material (Przyby 1992, Mejza et al. 1996). On the other hand, Szczerbowski (1993) considered exogenously feeding larvae as suitable stocking material. The larvae cultured for 26 days, as in this experiment, meet all the basic criteria of appropriate stocking material.

\section{REFERENCES}

Adamek J. 1986. Przemysłowy podchów wylęgu szczupaka. [Commercial rearing of pike larvae.] Gospodarka Rybna 37: (2-3): 14-17. [In Polish.]

Brett J.R. 1971. Satiation time, appetite and maximum food intake of sockeye salmon (Oncorhynchus nerka). Journal of the Fisheries Research Board of Canada 28: 409-415.

Bry C., Basset E., Rognon X., Bonamy F. 1992. Analysis of sibling cannibalism among pike, Esox lucius, juveniles reared under semi-natural conditions. Environmental Biology of Fishes 35: 75-84. 
Desvilettes C., Bourdier G., Breton J.-C. 1997. The effect of invertebrate diets on lipids, fatty acid composition and physiological condition of pike larvae (Esox lucius). Journal of Applied Ichthyology 13: 183-190.

Franklin D.R., Smith jr. L.L. 1963. Early life history of northern pike, Esox lucius L., with special reference to the factors influencing the numerical strength of year classes. Transactions of the American Fisheries Society 92: 91-110.

Giles N., Wright R.M., Nord M.E. 1986. Cannibalism in pike fry, Esox lucius L.: Some experiments with fry densities. Journal of Fish Biology 29: 107-113.

Górny W. 1992. The influence of water temperature on mortality, growth and cannibalism in the juvenile pike (Esox lucius L.). Archives of Polish Fisheries 1: 27 31.

Górny W., Wolnicki J. 1993. Technologia podchowu wylęgu szczupaka w warunkach kontrolowanych. [Technology of rearing pike larvae under controlled conditions.] Broszury Rybackie IRS (159): 1-19. [In Polish.]

Gres P., Lim P., Belaud A. 1996. Influence de la densité initiale de larves de brochet (Esox lucius L., 1758) en élevage intensif sur la survie, la croissance et la consommation journalière de nourriture (zooplancton, Chaoboridés). Bulletin Français de la Pêche et de la Pisciculture (343): 153-174.

Ivanova M.N., Svirskaâ A.N. [Svirskaya A.N.] 1995. O linejnom roste molodi ŝki Esox lucius (Esocidae). [On the linear growth of juvenile pike, Esox lucius (Esocidae).] Voprosy Ihtiologii 35: 835-839. [In Russian.]

Johnson B.M., Gilbert S.J., Stewart R.S., Rudstam L.G., Allen Y., Fago D.M., Dreikosen D. 1992 Piscivores and their prey. Pp. 319-352. In: Kitchell J.F. (ed.) Food web management: A case study of Lake Mendota, Wisconsin. Springer-Verlag, New York.

Karzinkin G.S. 1952. Osnovy biologičeskoj produktivnosti vodoemov. [Fundamentals of biological productivity of water bodies.] Piŝepromizdat, Moskva.

Koch W., Bank O., Jens G. 1982. Fischzucht: Lehrbuch für Züchter und Teichwirte. 5th edn. Verlag Paul Parey, Hamburg - Berlin.

Korwin-Kossakowski M. 1997. Kanibalizm inaczej czyli jak zjeść rodzeństwo po kawałku. [A different approach to cannibalism or how to eat your brothers and sisters step by step.] Komunikaty Rybackie 1997 (3): 1-3. [In Polish.]

Łuczyński M.J. 1992. Podchów wylęgu szczupaka żywionego paszą sztuczną. [Rearing of pike larvae fed artificial feeds.] Komunikaty Rybackie 1992 (2): 10-11. [In Polish.]

Łuczyński M.J., Przybył A., Madziar M. 1993. Próba podchowu wylęgu szczupaka przy użyciu pasz prototypowych. [An attempt to rear pike larvae on prototype feeds.] Komunikaty Rybackie 1993 (3): 9-10. [In Polish.]
Marmulla G., Rösch R. 1990. Maximum daily ration of juvenile fish fed on living natural zooplankton. Journal of Fish Biology 36: 789-801.

Mejza T., Kołdras M., Mejza A. 1996. Chów ryb dodatkowych w stawach karpiowych. [Culture of additional fish species in carp ponds.] Komunikaty Rybackie 1996 (1): 10-12. [In Polish.]

Morrow jr. J.V., Miller G., Killgore K.J. 1997. Density, size, and foods of larval northern pike in natural and artificial wetlands. North American Journal of Fisheries Management 17: 210-214.

Piesik Z., Świerczyńska I., Nguyen T.C. 1991. Bezkręgowce zasiedlajace bariery utworzone ze sztucznego podłoża w wodach płynących o różnym stopniu zanieczyszczenia. [Invertebrates colonizing barriers made of artificial substrate in streams representing different levels of pollution.] Zeszyty Naukowe Akademii Rolniczej w Szczecinie; Rybactwo Morskie i Technologia Żywności (143): 73-93. [In Polish.]

Poczyczyński P. 1996. Żywienie larw ryb - podstawy teoretyczne. I. Procesy trawienne larw ryb. [Feeding of fish larvae - theoretical considerations. I. Digestion processes in fish larvae.] Komunikaty Rybackie 1996 (3): 7-8. [In Polish.]

Przybył A. 1992. Możliwość podchowu juwenalnych stadiów larw szczupaka na paszy sztucznej. [Possibilities of rearing juvenile stages of pike larvae on commercial feeds.] Przegląd Rybacki 17: (5): 291295. [In Polish.]

Sakowicz L. 1939. Szczupak. Produkcja materiału zarybieniowego. [Pike. Production of stocking material.] Wydawnictwo Związku Organizacyj Rybackich R.P. B 11: 1-53. [In Polish.]

Scholz C. 1932. Experimentelle Untersuchungen über die Nahrungsverwertung des ein- und zweisommerigen Hechtes. Zeitschrift für Fischerei 30: 523-604.

Skov C., Jacobsen L., Berg S. 2003. Post-stocking survival of $0+$ year pike in ponds as a function of water transparency, habitat complexity, prey availability and size heterogeneity. Journal of Fish Biology 62: 311-322.

Szczepkowski M., Szczepkowska B., Ulikowski D. 1999. Podchów narybku szczupaka (Esox lucius) w obiegu recyrkulacyjnym na paszy sztucznej. [Rearing of pike (Esox lucius) fry on artificial feeds in recirculating water system.] Komunikaty Rybackie 1999 (6): 20-21. [In Polish.]

Szczerbowski J.A. (ed.) 1993. Rybactwo śródlądowe. [Inland fisheries.] Wydawnictwo IRS, Olsztyn. [In Polish.]

Szlauer B., Szlauer-Łukaszewska A. 1994. The effect of foil overgrown with periphyton on polluted standing waters. Polskie Archiwum Hydrobiologii 41: 251-263.

Szlauer L. 1979. Methods of utilisation of waste effluents from mineral fertilisers plants in carp fry cultures. Polskie Archiwum Hydrobiologii 26: 231-246.

Szlauer L. 1995. Możliwość intensyfikowania samooczyszczania się zbiorników wodnych poprzez zaw- 
ieszenie w nich folii polietylenowej. [Possibilities of water reservoirs self-purification intensifying with use of polyethylene foil hanged up in them.] Zeszyty Naukowe Uniwersytetu Szczecińskiego; Marine Sciences (171): 123-143. [In Polish.]

Szlauer L., Świerczyńska I. 1988. Rola spełniana przez sztuczne podłoże umieszczone w zanieczyszczonym strumieniu. [The role of artificial substrate in a polluted stream.] Zeszyty Naukowe Akademii Rolniczej w Szczecinie; Rybactwo Morskie i Technologia Żywności (133): 39-47. [In Polish.]

Wang N., Eckmann R. 1992. Effects of photoperiod, feeding regime and water temperature on the formation of daily growth increments in otoliths of larval pike (Esox lucius L.). Journal of Applied Ichthyology 8: $246-250$

Wolnicki J., Górny W. 1993. Zastosowanie pasz przemysłowych dla pstraga i węgorza w kontrolowanym podchowie wylęu szczupaka Esox lucius L. [Use of commercial trout- and eel feeds in controlled rearing of pike Esox lucius L. larvae.] Komunikaty Rybackie 1993 (2): 6-9. [In Polish.]

Wolnicki J., Górny W. 1995. Optymalna racja paszy w kontrolowanym podchowie wylęgu szczupaka (Esox lucius L.). [Optimal feed ration during controlled rearing of pike, Esox lucius L., larvae.] Komunikaty Rybackie 1995 (2): 21-23. [In Polish.]
Wolnicki J., Górny W. 1997. Effects of commercial dry diets and water temperature on growth and survival of northern pike, Esox lucius L., larvae. Polskie Archiwum Hydrobiologii 44: 377-383.

Wolnicki J., Kamiński R. 1998. Masowy podchów wylęgu szczupaka $\mathrm{z}$ zastosowaniem starterów. [Mass rearing of pike larvae with use of starter diets.] Pp. 83-90. In: Rybactwo Jeziorowe. III Krajowa Konferencja Krajowych Użytkowników Jezior, Pasym 8-10 June 2006. [In Polish.]

Wolska-Neja B. 2002. Conditions for cultivation of the crustacean Daphnia magna in a fish processing plant wastewater and optimal harvest level. Acta Scientiarum Polonorum, Piscaria 1: 91-104.

Załachowski W. 1970. Biologia rozwoju larw szczupaka w grupie Jezior Legińskich. [Biology of pike larval development in Legińskie Lake system.] Roczniki Nauk Rolniczych H 92 (3): 93-119. [In Polish.]

Załachowski W. 1973. Szczupak [Pike]. Państwowe Wydawnictwo Rolnicze i Leśne. Warszawa. [In Polish.]

Received: 7 February 2005

Accepted: 7 December 2006

Published electronically: 31 January 2007 